東北地方太平洋沖地震で被災した織笠川河口におけるサキグロタマツメタの 分布と同所に生息する貝類群集への捕食の影響

\title{
Distribution of the invasive snail Laguncula pulchella and the effect of its predation on the mollusk populations in the Orikasa River Estuary after the 2011 off the Pacific Coast of Tohoku Earthquake
}

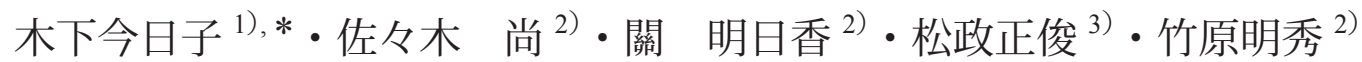 \\ 1)岩手大学三陸復興推進機構。 $\bar{T} 020-8550$ 岩手県盛岡市上田 3-18-8 \\ 2) 岩手大学人文社会科学部。 $\bar{T} 020-8550$ 岩手県盛岡市上田 3-18-34 \\ 3) 岩手医科大学全学教育推進機構教養教育センター生物学科。 T 028-3694 岩手県紫波郡矢巾町西徳田 2-1-1
}

Kyoko KINOSHITA $^{1 \text {, * }}$, Naoshi SASAKI ${ }^{2)}$, Asuka SEKI ${ }^{2)}$, Masatoshi MATSUMASA ${ }^{3)}$ and Akihide TAKEHARA ${ }^{2)}$

1) Organization of Revitalization for Sanriku-region, Iwate University, 3-18-8 Ueda, Morioka, Iwate 020-8550, Japan

2) Faculty of Humanities and Social Sciences, Iwate University, 3-18-34 Ueda, Morioka, Iwate 020-8550, Japan

3) Department of Biology, Center for Liberal Arts and Sciences, Iwate Medical University, 2-1-1 Nishitokuta, Yahaba, Iwate 0283694, Japan

\begin{abstract}
The present study was conducted to elucidate the distribution of the invasive alien snail Laguncula pulchella and its effect on the native mollusk populations in the Orikasa River Estuary, Iwate Prefecture after the 2011 Great East Japan Earthquake. Laguncula pulchella was the most abundantly distributed in the area with sandy sediment among the three survey areas. Although the number of L. pulchella increased in an area with gravelly sediment during the second year of the study period, the higher gravel content $(>54 \%)$ might have inhibited the distribution of L. pulchella in another gravelly area. The clam Ruditapes philippinarum was the dominant species and main prey of L. pulchella in the study area. There was a positive correlation between predator and prey sizes, and the coefficient $(0.53)$ tended to be lower than that reported by the earlier studies. In the estuary, L. pulchella might have preyed on clams smaller than its preferred size. The density of $R$. philippinarum decreased within the distribution area of L. pulchella; however, its density was maintained in the areas with gravelly sediment. These results indicate that the heterogeneity of sediment with gravel after the earthquake limited the distribution of L. pulchella, and thereby contributed to the maintenance of the native mollusk populations.
\end{abstract}

Key Words: alien predator, Iwate, mollusk, Naticidae, sediment, tsunami

\section{はじめに}

サキグロタマツメタLAguncula pulchella（鳥越・稲葉 2011）は，生きた巻貝や二枚貝の貝殼に穴を開けて，その 軟体部を食べるタマガイ科の貝食性巻貝である。本種は日 本ベントス学会では絶滅危惧 IA 類に指定され, 本来の分 布域は瀬戸内海, 有明海, 韓国, 中国とされており, 東日 本太平洋沿岸域には生息していなかった（佐藤・田北 2000; 日本ベントス学会 2012). しかし，アサリRuditapes philippinarum の移植放流とともに持ち込まれて増殖し, 宮

Received 2 February 2017 Accepted 17 June 2017

* Corresponding author

E-mail: kinoshita.kyoko@mbn.nifty.com
城県や福島県のアサリ漁場において，アサリの食害が報告 されている（酒井 2000; 大越 2004; 冨山ら 2011; 大越・大 越2011).

岩手県山田町織笠川の河口干潟は県内有数の潮干狩り場 であったが，潮干狩り用に放流したアサリとともにサキグ ロタマツメタが移入され，2005 年にアサリの食害が確認 された (山田町私信)。その後, サキグロタマツメタとそ の卵塊の駆除が行われたが, 食害の影響により 2007 年と 2008 年には潮干狩りが中止された（山田町私信）。織笠川 の河口域は 2011 年の東北地方太平洋沖地震 (以下, 東北 沖地震と略する) が発生した時に, 約 $9 \mathrm{~m}$ の津波が襲来 し (原口・岩松 2011), さらに $50 \mathrm{~cm}$ 以上の地盤沈下が生 じた（三冬社編集部 2013）影響により, 干潟の面積が減 少した（環境省自然環境局 2013）。 その後の底生生物の生 息状況については, 東北沖地震直後の 2011 年より調査が 
行われ, 底生生物の種数は 2011 年に地震の前よりも著し く減少したが, 2012 年には出現種数の増加傾向が認めら れた（木下 2016; Kinoshita \& Matsumasa 2016）。サキグロ タマツメタも 2011 年に生息が再確認された（環境省自然 環境局 2013). 本種のような外来性の上位捕食者は, 被食 者へのトップダウン効果が大きい(例えば Buhle \& Ruesink 2009; Chiba \& Sato 2013）ことから, 地震や津波の 影響を受けた貝類群集にさらなる影響を与えることが予想 された。また織笠川の潮干狩りは, 地域にとって重要な観 光イベントのひとつであったが, 東北沖地震の後はイベン トが中止されており（木下 2016）再開を望む声が大きい。 三陸沿岸では東北沖地震の後, 織笠川と同様に潮干狩りが 中止されている地域が多く, アサリの回復状況やそれを取 り巻く生物環境を明らかにすることは, 潮干狩り再開に向 けた情報を地元の漁業者や地方自治体に提供できると考え られる。

そこで本研究では, 東北沖地震で被災した織笠川の河口 域において, サキグロタマツメタの分布と環境要因, 特に 底質の粒度組成との関係について調査を行った. さらに本 種の被食対象である巻貝・二枚貝の生息状況を調査し, 本 種の貝類群集への影響を検討した。

\section{材料と方法}

\section{調査地の概要と調査範囲}

調査を行った織笠川の河口域 $\left(39^{\circ} 26^{\prime} \mathrm{N}, 141^{\circ} 57^{\prime} \mathrm{E}\right)$ は, 山田湾の南西部に位置する. 東北沖地震が発生する前の織 笠川の干潟は, 織笠大橋（Fig. 1）よりも海側まで出現し たが, 地震直後から織笠大橋の手前までしか干出しなく なった。調查範囲は 2013 年 3 月の大潮の最大干潮時に干 出した場所を中心に, 河口域の北部から南部にかけて約 9,000 $\mathrm{m}^{2}$ を設定した。調査範囲は南北に 3 つの区画に均等 に分け (Fig. 1, Area A C ), それぞれの調査区画内に調査 地点を設定した（Fig. 1, Stn $\mathrm{A} \sim \mathrm{C}$ ). なお, 調査地周辺は 災害復旧事業が進められており，2013 年 10 月には調査範 囲の南部でかさ上げ工事が，2014 年 4 月には調査範囲の 北西部で水門建設のための地盤改良工事が始まった。これ らの工事にともない調査区画の一部（Fig. 1）は埋め立て られたが，その規模はわずかであることから，調査範囲の 修正は行なわなかった。

\section{底質の粒径分析}

サキグロタマツメタの分布を規定する環境要因として底 質に着目し, 調査地の堆積物を採集して粒度分析を行っ た. 堆積物の採集は 2013 年 4 月から 3 カ月毎, ならびに 調査終了時の 2015 年 3 月に行った. 各調査地点において, 内径 $5 \mathrm{~cm}$ の円形の筒を海底に 1 回差し込み, 深さ $5 \mathrm{~cm}$ ま での堆積物を採集して実験室内に持ち帰った。実験室内に おいて, 堆積物中に過酸化水素水を加えて有機物を分解

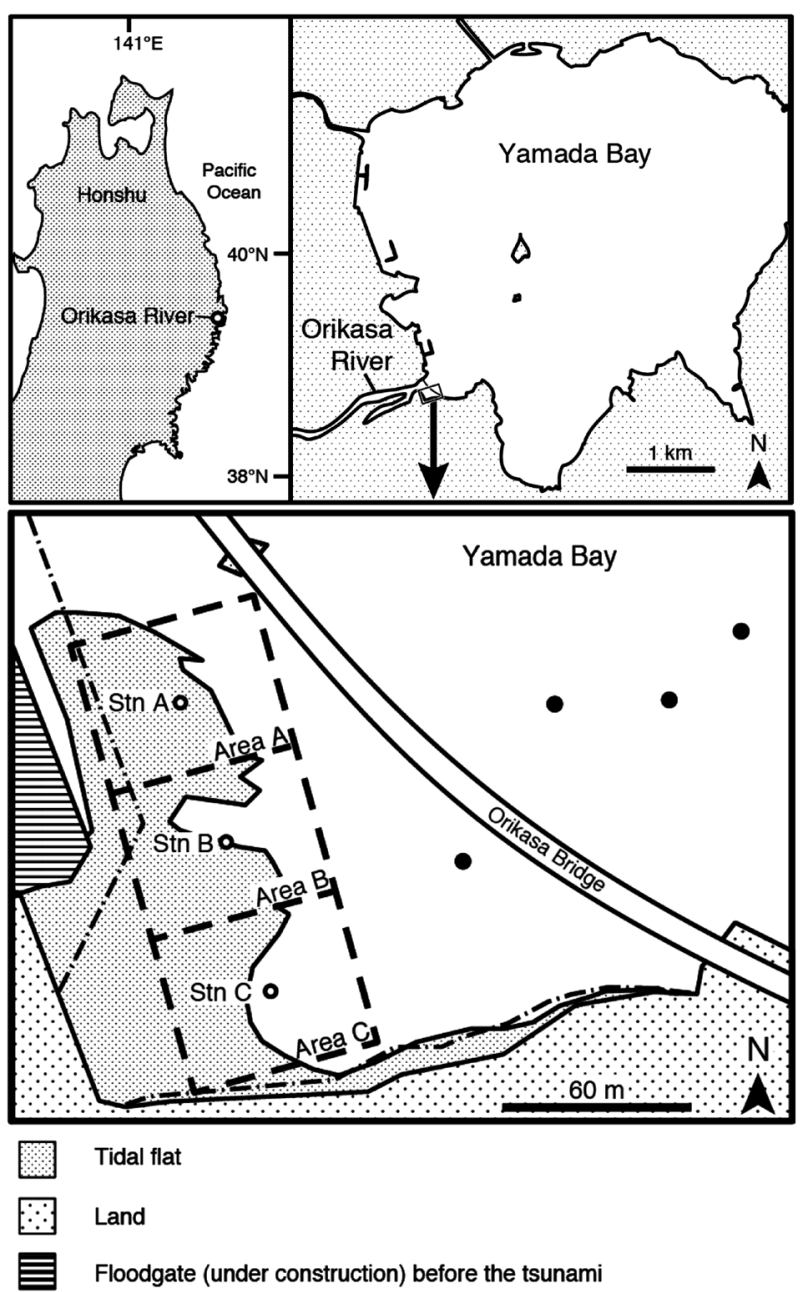

Fig. 1. Survey area. Broken lines indicate the search area. Broken-and-dotted lines indicate the range of reconstruction work. Solid circles indicate sites where the sea snails were observed before 2011 (Yamada Town personal communication).

し，湿式ふるいわけ法にて堆積物の粒径を 7つ（0.063 mm 以下, $0.063 \sim 0.125 \mathrm{~mm}, 0.125 \sim 0.25 \mathrm{~mm}, 0.25 \sim 0.5 \mathrm{~mm}$, 0.5 1 $\mathrm{mm}, 1 \sim 2 \mathrm{~mm}, 2 \mathrm{~mm}$ 以上）に区分した.

\section{サキグロタマツメタの分布とサイズ構造，捕捉した貝類}

サキグロタマツメタの分布状況を明らかにするために, 目視による分布調査を, 2013 年 4 月〜2015 年 3 月にかけ て毎月 1 回, 大潮干潮時に実施した（以下,「分布調査」 と称する). 分布調査は原則として 2 名で実施し, 調査範 囲（Area A C ）内を 1 人が 1 時間捜索し，発見した個体 の位置を記録し，その個体を採集した。調査人数が 2 名以 上（最高 6 名）の場合は, 人数の増加に応じて調查時間を 短縮した. 分布調査で得られたサキグロタマツメタは, 調 查区画ごとに採集個体数を算出した.

分布調査では, サキグロタマツメタの小型個体の発見が 難しいこと（大越・大越 2011）から, 一定面積の堆積物 を掘り出して捜索する定量調査も実施した（以下，「定量 
調査」と称する)，調查範囲内に $50 \mathrm{~cm} \times 50 \mathrm{~cm}$ の方形枠を 設け，その中の堆積物を目合い $1 \mathrm{~mm}$ の網を張ったジョレ ン（株式会社スノーピーク製：貝取りジョレン（中））を 用いて染さ $10 \mathrm{~cm}$ まで掘り出し，これを目合い $1 \mathrm{~mm} の ふ$ るいでろるい，残椬からサキグロタマツメタを採集した． この調查は 2013 年 4 月と 5 月では毎月 16 回 $\left(4 \mathrm{~m}^{2}\right)$, 2013 年 6 月 2015 年 3 月では毎月 20 回 $\left(5 \mathrm{~m}^{2}\right)$ で行っ た。なお，定量調查は調査範囲内において，特定の場所に 偏らないように実施した。その他, 調査範囲外（浜に打ち 上げられた生貝）や，分布調査の時間外に発見された個体 も採集し，特記事項として記録した，全ての調査で採集し たサキグロタマツメタの殼高をノギスにて $0.01 \mathrm{~mm}$ 精度 で測定した（株式会社ミットヨ製：CD67-S15PM）。サキ グロタマツメタは貝類を捕捉すると，粘液の膜で包み込 み，そのまま移動することが知られている（大越・大越 2011）ことから，サキグロタマツメタが粘膜を出して貝類 を捕捉していた場合，その貝の種類を同定した。捕捉され た個体のうち，貝殼に穴を開けられた個体はサキグロタマ ツメタが捕食に成功した個体であると判断した（以下， 「被食個体」と称する），被食個体がアサリの場合，アサリ の殼長を測定し，捕食していたサキグロタマツメタの殼高 との関係を求めた。さらに，田邊（2012）が示した被食捕 食係数（アサリの殼長 $(\mathrm{mm}) /$ サキグロタマツメタの殼高 $(\mathrm{mm}))$ を求め, アサリの殼長とサキグロタマツメタの殼 高との関係を明らかにした。

\section{貝類と被食痕のある貝殼の種組成とサイズ構造}

調査は 2013 年 4 月から 2015 年 3 月に，1 月を除いた毎 月 1 回実施した。各調査地点 $(\mathrm{S} \operatorname{tn} \mathrm{A} \sim \mathrm{C})$ において, 内径 $15 \mathrm{~cm}$ (面積 $176.6 \mathrm{~cm}^{2}$ ）の塩ビパイプ製の採泥器（自製） を用いて, 堆積物を深さ $20 \mathrm{~cm}$ まで円柱状に掘り出し, こ れを目合い $1 \mathrm{~mm}$ のふるいにかけて，残椬を試料とした （以下，「現存量調查」と称する)。この作業を, 調査地点 ごとに 5 回ずつ実施した。試料は $10 \%$ 中性ホルマリンで 固定した後, サキグロタマツメタの被食者の可能性がある 巻貝と二枚貝，さらに本種による被食痕のある貝款を採集 した。なお，山田湾ではタマガイ科のツメタガイ Glossaulax didyma が発見されており, ツメタガイが捕食した貝の 貝殸が調査範囲に流入した可能性はあるが，本研究の調査 範囲におけるタマガイ科の生貝はサキグロタマツメタのみ であったことから，被食痕のある貝殼は本種によるものと して扱った。また，被食痕のある貝殼については，殼長や 殸高が確認できるものを対象とし，破損しているものは除 外した。サキグロタマツメタによる食害の影響を調査した 既報では，両殼が揃った貝款から被食痕のある貝殼を対象 としている（大越・大越 2011）が，本研究では堆積物を ふるいにかける際に両殼が分離する事例があり，本種によ る被食の影響を過小評価することが懸念されたため，片款 のみの貝殼も対象とした，貝類のうち，個体数がもっとも
多いアサリを対象に，生貝および被食痕のある貝殼の殼長 をノギスで測定した。

\section{統計解析}

2 群の比較においては Welch の t-test を用い, 3 群の比 較では Kruskal-Wallis 検定の後, Steel-Dwass の多重比較 を行った。解析には Microsoft Excel およびアドインソフト Statcel 3 を用いた.

\section{東北沖地震の前に採集記録がある海域の生息状況の調査}

東北沖地震の前に行われたサキグロタマツメタの生息調 査によって個体が確認され（山田町 私信），地震後に潮下 帯となった海域の同じ地点（Fig. 1，黒丸印）において, 2014 年 5 月に船上からジョレンを用いて海底を掘削した。 掘り出した堆積物から, サキグロタマツメタやアサリ，被 食痕のある貝殼の有無を調べた。

\section{結果}

\section{底質の粒度組成}

調査地の粒度組成は碟（粒径 $2 \mathrm{~mm}$ 以上）が主体であっ たが，その比率は地点によって異なった（Fig. 2)。Stn A では礫の割合は調査期間を通じて 54\%以上（54.1〜 $91.9 \%$, 平均 $76.6 \%$ ）を占め, 礫以外は，各粒径で平均 $9 \%$ 未満（最大 $18 \%$ 未満）であった。Stn B では礫の割合 は Stn A よりも低かった (44.4〜86.0\%，平均 62.4\%)。礫

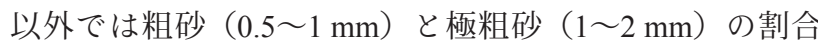
が，それぞれ平均で $12.6 \%$ と $11.2 \%$ であった．Stn Cでは 礫の割合は調査期間を通じて $48 \%$ 未満（9.3〜 48.0\%，平 均 26.2\%）であった。礫以外では中砂（0.25〜0.5 mm）と 粗砂の割合が，それぞれ平均で $17.8 \%$ と $17.2 \%$ であった。

\section{サキグロタマツメタの分布とサイズ構造}

分布調査の結果，サキグロタマツメタが多く発見された 区画は Area C で総個体数は 538 個体，以下 Area B で 217 個体，Area A で 5 個体であった（Fig. 3)。全ての調査期間 で得られた毎月の個体数をもとに，調査区画の間で比較し た結果，有意な違いが認められた（Kruskal-Wallis test, $H=34.5, P<0.001$, Steel-Dwass test, 全ての組み合わせにつ いて $P<0.001)$. 同様に，全ての調査区画において，2014 年〜2015 年に採集された個体数の方が，2013 年〜2014 年 に採集された個体数よりも多かった。分布調査において, 採集月による個体数の変動はみられたものの，明瞭な季節 変化の傾向は認められなかった。そこでArea B と Area C を対象に，毎月の個体数を年ごとに比較したところ，Area $\mathrm{B}$ でのみ有意な違いが認められた（Welchの $\mathrm{t}$-test, $\mathrm{t}_{11}=$ $2.60, P<0.05)$.

全ての調査によって，サキグロタマツメタが最も多く採 集されたのは 2014 年 12 月の 180 個体（Fig. 4）で，分布 

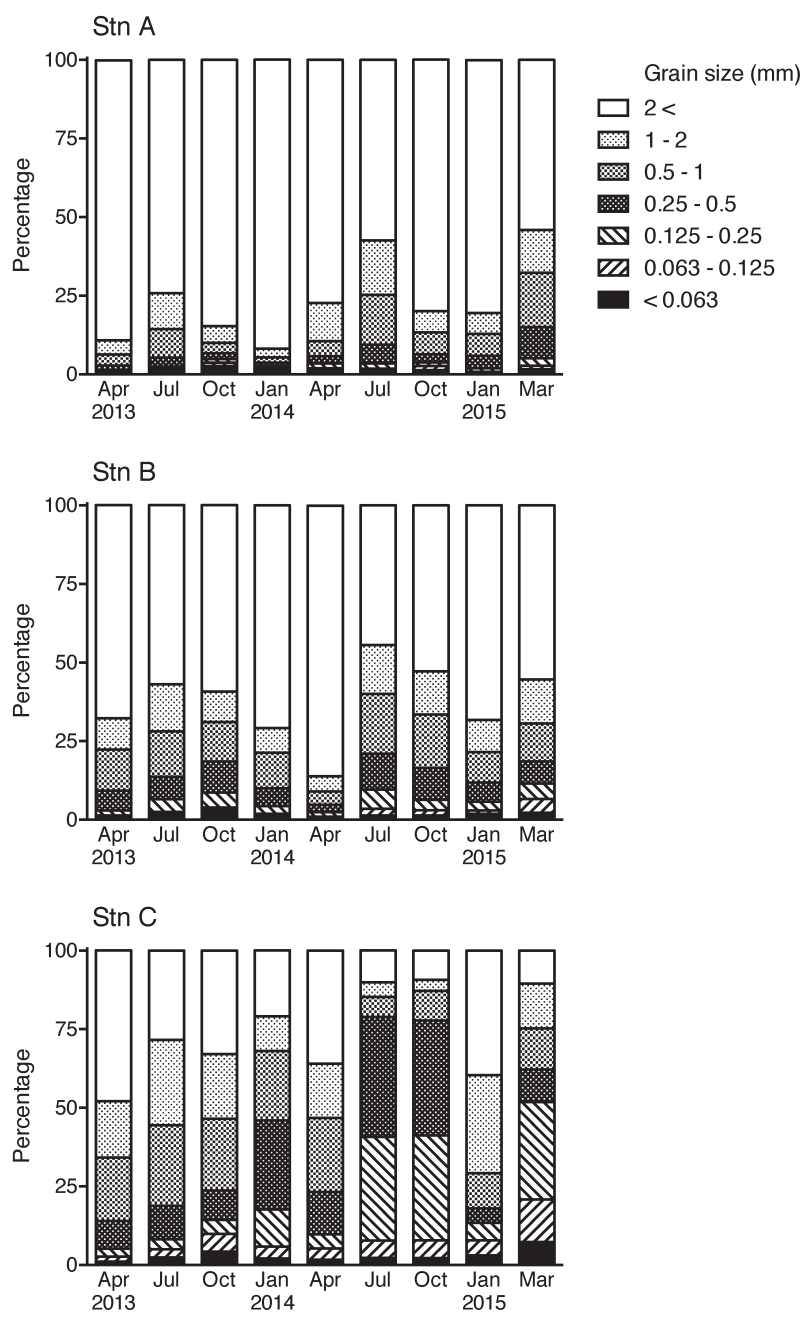

Fig. 2. Grain-size composition of the sediment.

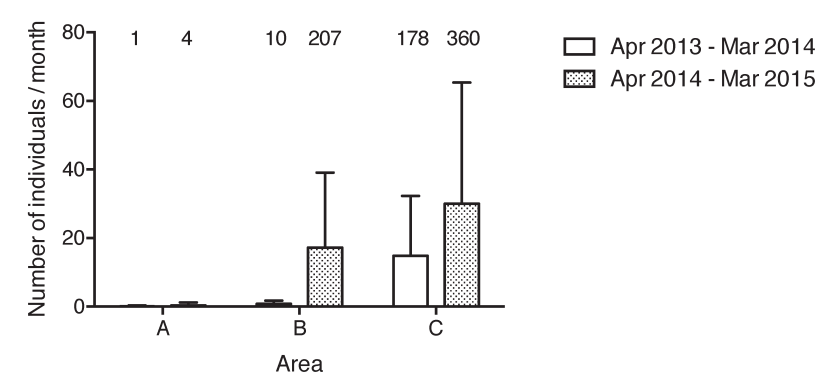

Fig. 3. Mean and positive standard deviation (SD) of number of Laguncula pulchella in the study area. The number above the bars indicates the total number of individuals in the distribution survey.

調査で採集された割合が高かった。なお，2013 年 11 月の 調査では前日までの荒天の影響で浜に打ち上げられた生貝 が多く, また 2013 年 12 月の調査では荒天で視界が悪く, サキグロタマツメタは採集されなかった。 定量調査に基づ くサキグロタマツメタの平均密度は 2.1 個体 $/ \mathrm{m}^{2}$ で, 最も 多く採集されたのは 2013 年 10 月の 33 個体, 密度に換算 すると 6.6 個体 $/ \mathrm{m}^{2}$ であった. サキグロタマツメタの最小
個体は 2013 年 6 月の殼高 $5.24 \mathrm{~mm}$, 最大個体は 2015 年 1 月の $51.03 \mathrm{~mm}$ であった。殼高 $10 \mathrm{~mm}$ 未満のサキグロタマ ツメタは, すべて定量調査で採集された。

\section{サキグロタマツメタが捕捉していた貝類}

貝類を捕捉していたサキグロタマツメタは 31 個体で, 捕捉された貝類はアサリが 28 個体，ヒメシラトリ Macoma incongrua が 2 個体，イソシジミNuttallia japonica が 1 個体であった。このうち被食個体は，アサリが 13 個体， ヒメシラトリとイソシジミは各 1 個体であった。サキグロ タマツメタの殼高とアサリの殼長との間には有意な正の相 関が認められた（Fig. 5A, y=0.419 x + 2.780, $\mathrm{R}^{2}=0.633$, $P<0.01)$. アサリーサキグロタマツメタの被食捕食係数 は, 平均 $0.53 \pm 0.09$ （標準偏差）で, サキグロタマツメタ の殼高と被食捕食係数の間には相関が認められなかった （Fig. 5B, $\mathrm{R}^{2}=0.070, P=0.383$ ).

\section{貝類の種組成とアサリのサイズ構造}

現存量調査の結果, 全ての調査地点においてアサリの密 度は最も高かったが, その変動は地点によって異なった （Fig. 6）。アサリの密度は Stn A と Stn B では 2013 年 10 月 に最も高く（Stn A: 2,242 個体 $/ \mathrm{m}^{2}$, Stn B: 2,174 個体 $/ \mathrm{m}^{2}$ ), その後は変動しながら $\operatorname{Stn} \mathrm{A}$ では平均密度 669 個体 $/ \mathrm{m}^{2}$ で, Stn B では平均密度 470 個体 $/ \mathrm{m}^{2}$ で推移した. Stn C のアサ リの密度は調査を開始した 2013 年 4 月は他の地点よりも 高く, 2013 年 5 月に 1,540 個体 $/ \mathrm{m}^{2}$ を記録したが, その後 は減少し, 2014 年 2 月以降は 60 個体 $/ \mathrm{m}^{2}$ 未満, 2014 年 12 月以降は採集されなかった。 アサリ以外の貝類は, 全ての 地点でエゾチグサ Cantharidus jessoensis とヒメシラトリが 採集され，エゾチグサは $\operatorname{Stn} \mathrm{B}$ の平均密度が 66 個体 $/ \mathrm{m}^{2}$ で 最も高かった．ヒメシラトリは $\operatorname{Stn} C$ の平均密度が 123 個 体 $/ \mathrm{m}^{2}$ で最も高かったが，2014 年 2 月以降は 100 個体 $/ \mathrm{m}^{2}$ 以下であった. 各地点の優占種は, Stn A ではホトトギス ガイ Arcuatula senhousia, Stn B ではホトトギスガイとホソ ウミニナ Batillaria attramentaria, Stn Cではホソウミニナ とウメノハナガイ Pillucina pisidium であった。 なお, 現存 量調査に基づくサキグロタマツメタの平均密度は, Stn A で 0.5 個体 $/ \mathrm{m}^{2}, \operatorname{Stn} \mathrm{B}$ で 1.5 個体 $/ \mathrm{m}^{2}, \operatorname{Stn} \mathrm{C}$ で 10.3 個体 $/ \mathrm{m}^{2}$ であった.

アサリの殼長組成は, 2013 年 4 月は殼長 1 ～16 mm の 割合が高く $(97 \%), 2014$ 年 5 月は殼長 11〜26 mm の割合 (92\%), 調査終了時の 2015 年 3 月は殼長 19〜31 mm の割 合（82\%）がそれぞれ高かった（Fig. 7). Stn Cでは， 2013 年 12 月までは殼長 $20 \mathrm{~mm}$ 以上の個体が採集されて いたが，2014年 2 月以降は殼長 $18.76 \mathrm{~mm}$ の個体が 2014 年 5 月に採集されたのを除いて, 殸長 $11 \mathrm{~mm}$ 未満の個体 しか採集されなかった。 

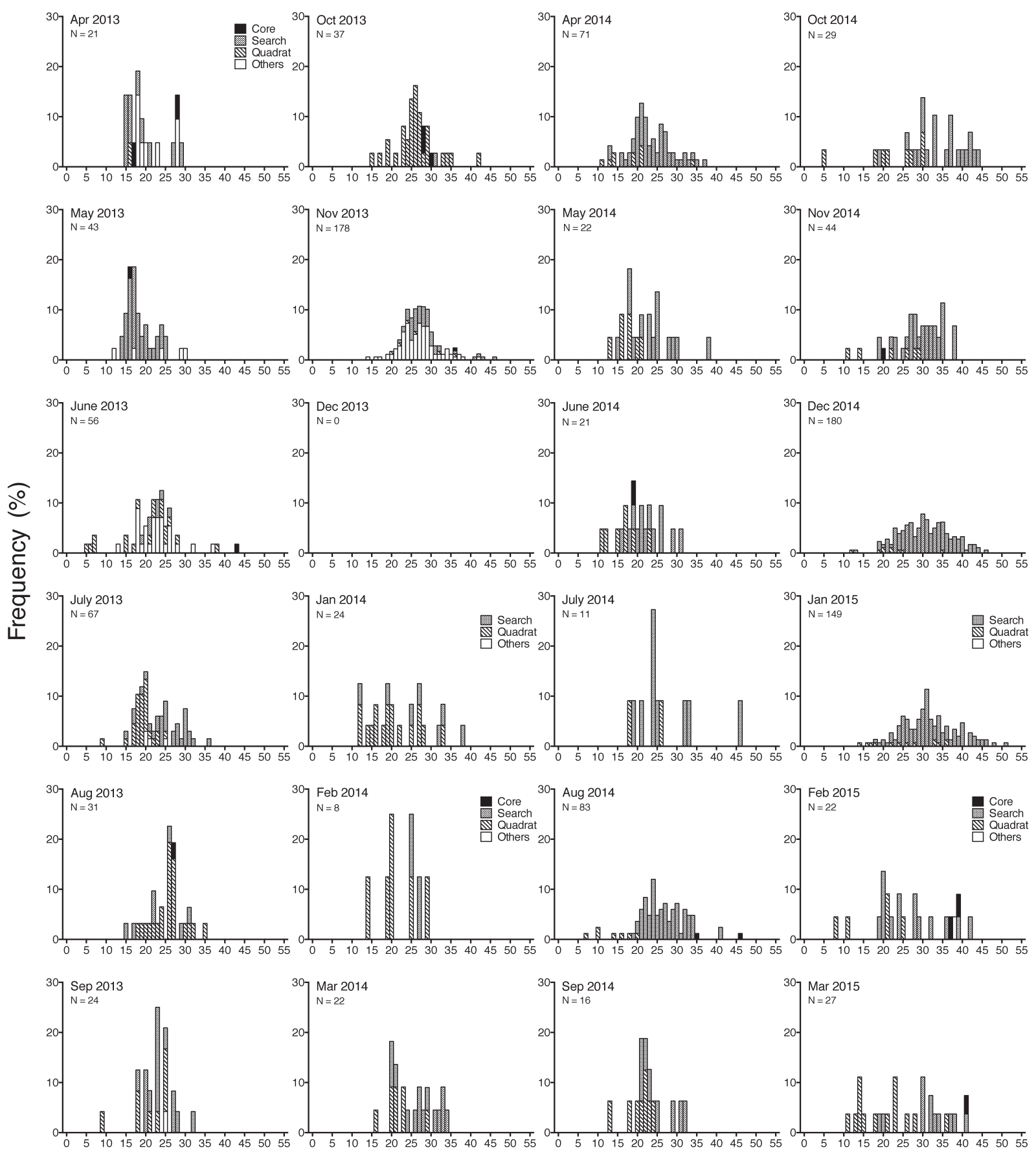

\section{Shell height $(\mathrm{mm})$}

Fig. 4. Frequency distribution of the shell height of Laguncula pulchella.

\section{被食痕のある貝殼の種組成とアサリのサイズ組成}

被食痕のある貝殼は 1,009 個が発見され，そのうち 982 個（97\%）はアサリであった（Table 1)。アサリ以外の貝 殼はヒメシラトリの 18 個を除き， 3 個未満であった。ア サリの貝殸は Stn Cで 806 個と最も多く, Stn Bでは 170 個，Stn A では 6 個であった. 2 年間の調査期間において, アサリの貝款は Stn B と Stn C では，2014〜2015 年の方が 2013〜2014 年よりも多く発見された。貝殼の殼長では,
2013〜2014 年の Stn B は $14.0 \pm 4.0 \mathrm{~mm}$ (平均土標準偏差),

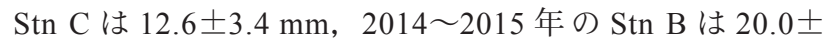
$5.7 \mathrm{~mm}, \operatorname{Stn} C$ は $8.5 \pm 3.6 \mathrm{~mm}$ で，いずれの期間も $\operatorname{Stn} \mathrm{B}$ と Stn C の間に有意な違いが認められた（Fig. 8, Welch の t-test, $2013 \sim 2014$ 年 : $\mathrm{t}_{79.2}=2.48, P<0.05,2014 \sim 2015$ 年 : $\mathrm{t}_{128.1}=$ $20.51, P<0.01)$. 同様に, 両調查地点とも 2014 2015 年と 2013〜2014 年の間に有意な違いが認められた（Welch の ttest, Stn B: $\mathrm{t}_{154.2}=7.99, P<0.01$, Stn $\mathrm{C}: \mathrm{t}_{473.3}=15.26, P<0.01$ ). 

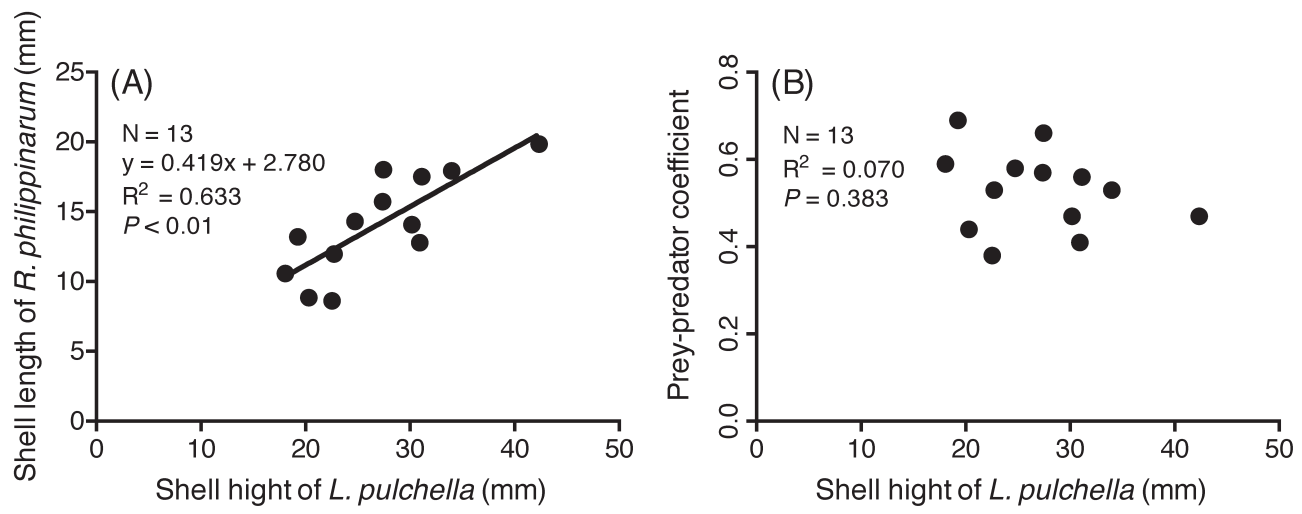

Fig. 5. Relationship between the shell height of Laguncula pulchella and shell length of Ruditapes philippinarum (A), and the prey-predator coefficient (B)
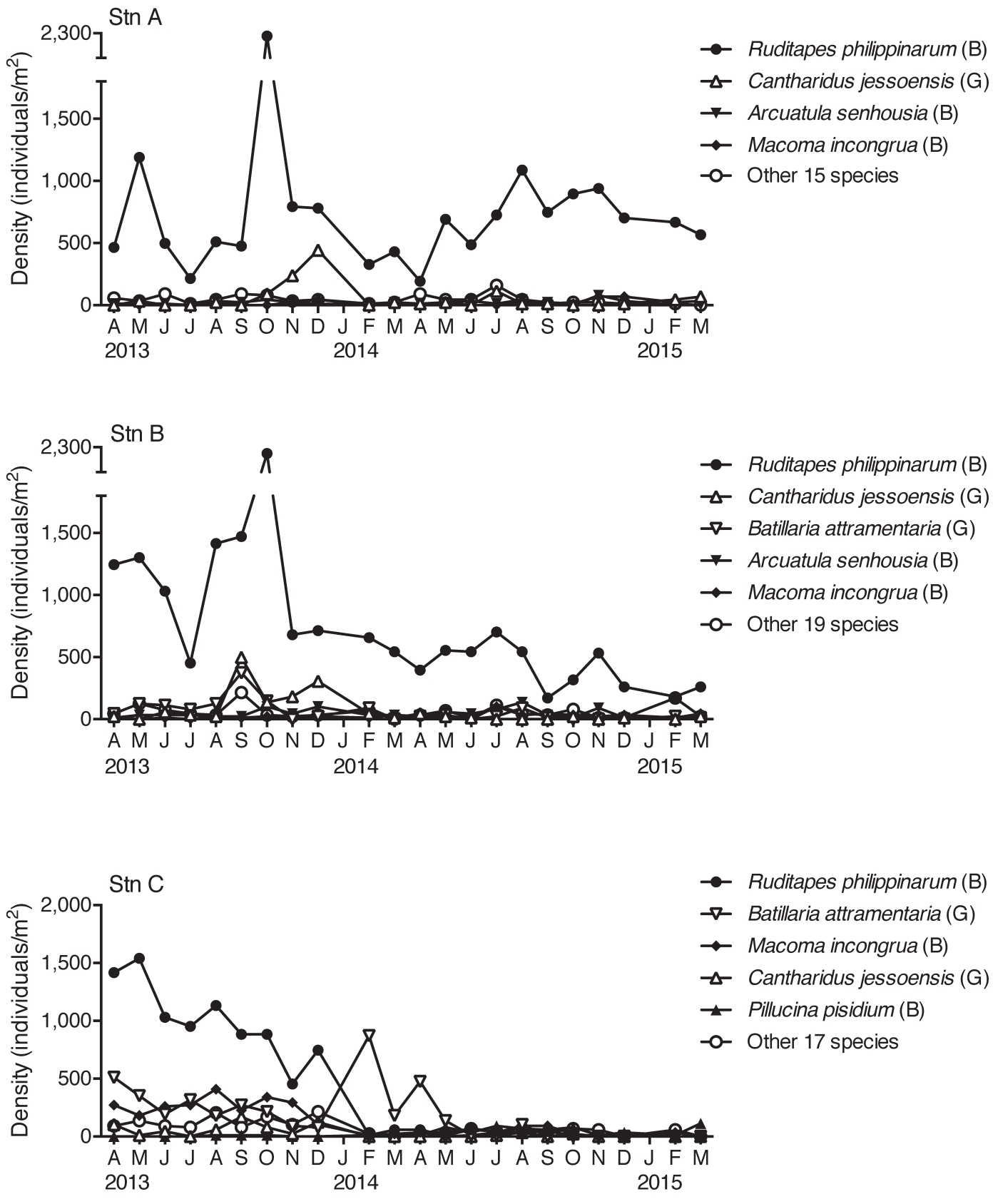

Fig. 6. Seasonal fluctuations in the density of gastropods and bivalves. G, Gastropoda; B, Bivalvia. 


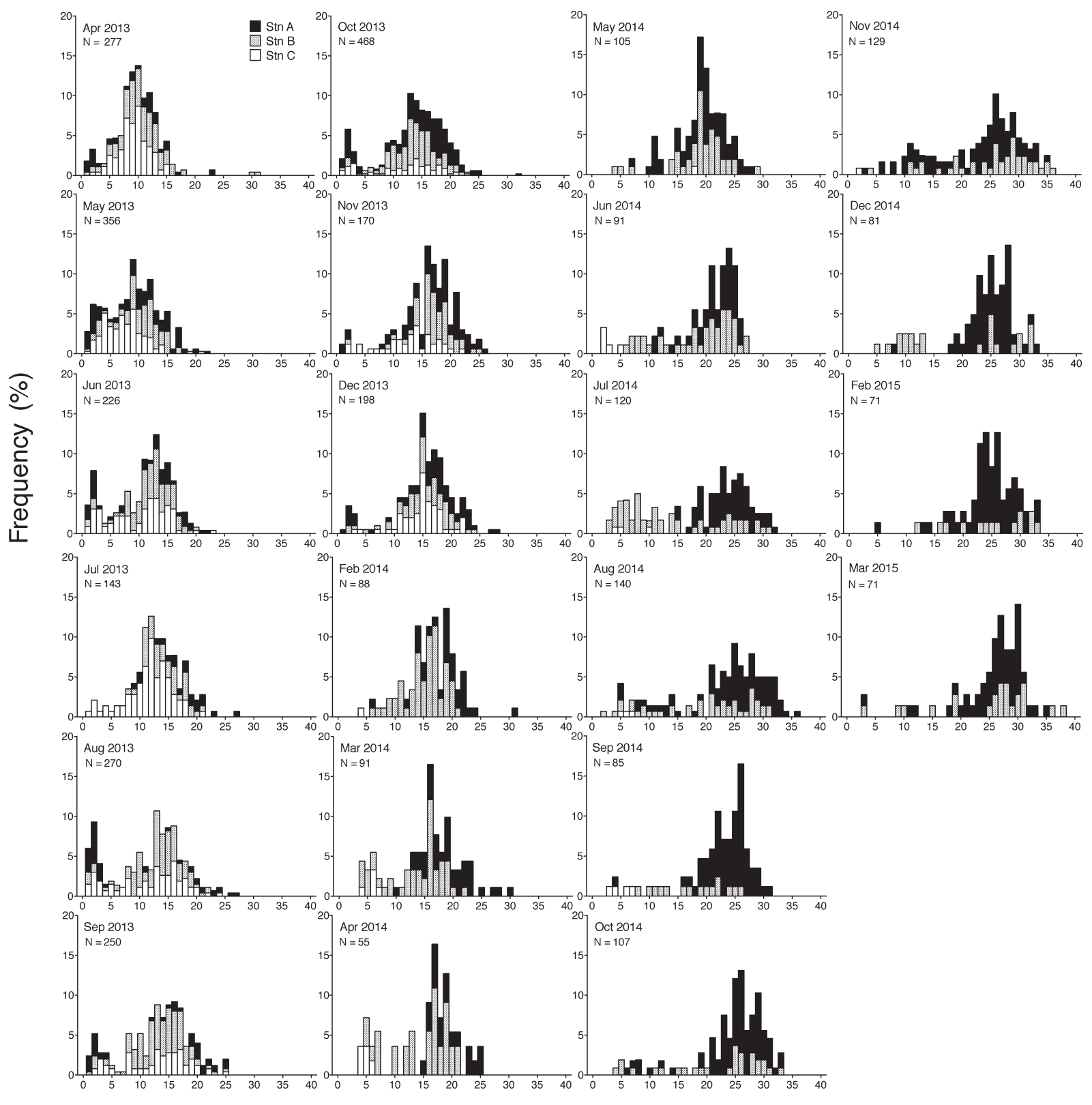

Shell length $(\mathrm{mm})$

Fig. 7. Frequency distribution of the shell length of Ruditapes philippinarum.

Table 1. Number of drilled seashells found at Stn A-C. The total survey area of each station was $0.97 \mathrm{~m}^{2} /$ year.

\begin{tabular}{|c|c|c|c|c|c|c|c|c|c|c|c|c|c|}
\hline \multirow[b]{2}{*}{ Class } & \multirow[b]{2}{*}{ Species } & \multicolumn{3}{|c|}{ Stn A } & \multicolumn{3}{|c|}{ Stn B } & \multicolumn{3}{|c|}{$\operatorname{Stn} C$} & \multicolumn{3}{|c|}{ Total } \\
\hline & & $\begin{array}{l}\text { Apr. 2013- } \\
\text { Mar. } 2014\end{array}$ & $\begin{array}{l}\text { Apr. 2014- } \\
\text { Mar. } 2015\end{array}$ & Total & $\begin{array}{l}\text { Apr. 2013- } \\
\text { Mar. } 2014\end{array}$ & $\begin{array}{l}\text { Apr. 2014- } \\
\text { Mar. } 2015\end{array}$ & Total & $\begin{array}{l}\text { Apr. 2013- } \\
\text { Mar. } 2014\end{array}$ & $\begin{array}{l}\text { Apr. 2014- } \\
\text { Mar. } 2015\end{array}$ & Total & $\begin{array}{l}\text { Apr. 2013- } \\
\text { Mar. } 2014\end{array}$ & $\begin{array}{l}\text { Apr. 2014- } \\
\text { Mar. } 2015\end{array}$ & Total \\
\hline \multirow[t]{6}{*}{ Bivalvia } & Ruditapes philippinarum & 5 & 1 & 6 & 59 & 111 & 170 & 236 & 570 & 806 & 300 & 682 & 982 \\
\hline & Macoma incongrua & 0 & 0 & 0 & 0 & 0 & 0 & 7 & 11 & 18 & 4 & 14 & 18 \\
\hline & Nuttalia japonica & 0 & 1 & 1 & 1 & 0 & 1 & 0 & 1 & 1 & 0 & 1 & 3 \\
\hline & Pseudocardium sachalinense & 0 & 0 & 0 & 0 & 0 & 0 & 0 & 1 & 1 & 1 & 0 & 1 \\
\hline & Protothaca euglypta & 0 & 0 & 0 & 0 & 1 & 1 & 0 & 0 & 0 & 0 & 0 & 1 \\
\hline & Mya arenaria oonogai & 0 & 0 & 0 & 0 & 0 & 0 & 1 & 0 & 1 & 0 & 1 & 1 \\
\hline \multirow[t]{3}{*}{ Gastropoda } & Nassariidae sp. & 0 & 0 & 0 & 0 & 0 & 0 & 2 & 0 & 2 & 0 & 2 & 2 \\
\hline & Batillaria attramentaria & 0 & 0 & 0 & 0 & 0 & 0 & 0 & 1 & 1 & 1 & 0 & 1 \\
\hline & Total & 5 & 2 & 7 & 60 & 112 & 172 & 246 & 584 & 830 & 306 & 700 & 1,009 \\
\hline
\end{tabular}




\section{東北沖地震の前に採集記録がある海域の生息状況の調査}

現在は潮下帯であり, 東北沖地震の前にはサキグロタマ ツメタの採集記録があった海域では，本種と被食痕のある 貝殸は採集されなかったが，アサリは採集された。調査時 の水深は $0.2 \mathrm{~m} \sim 1.4 \mathrm{~m}$ の範囲であった.

\section{考察}

\section{サキグロタマツメタの分布}

分布調査の結果, サキグロタマツメタは底質に砂の割合 が高い Area Cで多く発見された（Fig. 3）が, 調査期間の 後半になると, Area Cよりも礫の割合が高い Area Bで発 見される個体が増加した。この理由として, Area Cではサ キグロタマツメタが捕食する貝類, 特にアサリの密度が著 しく減少した（Fig. 6）ために，アサリの密度が高いArea Bに分布を拡大させたことが考えられる。しかし，底質に 礫の割合が最も高いArea A ではアサリの密度が高いにも かかわらずサキグロタマツメタの発見頻度が低かったこと から, 底質に占める礫の割合が高いことは本種の分布を阻 害する要因の一つになっていると推定された。 また, すべ ての区画において，2014 年〜2015 年に発見されたサキグ ロタマツメタの個体数の方が，2013 年〜2014 年に発見さ れた個体数よりも多かったことから，本種は増加傾向にあ ることが示唆された。 ただし, 分布調査では殼高 $10 \mathrm{~mm}$ 未 満の小型個体は発見できないという, 手法上の課題も明ら
かになった、サキグロタマツメタの小型個体は目視での発 見が難しいことは, 大越・大越（2011）によって報告され ているままた，サキグロタマツメタの分布と底質条件につ いては, 宮城県万石浦のアサリ漁場で調査され, 底質が粒 径 2 20 mm の砂利や貝殼が混在した干潟では, 砂質の干 潟に比べて本種の生息数が少ないことが報告されている （酒井・須藤 2006）。本研究では, 従来の知見と一致する結 果が得られた。須藤（2011）は，粉砕カキ殼を混合させた 砂床を用いてサキグロタマツメタの室内飼育試験を行い, カキ殼を混合させた砂床では, 餌として与えたアサリの被 食数が減少したことから，底質が本種の捕食に影響を及ぼ すことを示している．底質がサキグロタマツメタの分布に 及ぼす要因として, 捕食行動への影響の他に, 卵塊の形成 への影響が考えられる．本種を含むタマガイ科の貝は，砂 と自身が出す粘液を使って「砂茶碗」と呼ばれる卵塊を形 成する. 大越・山内（2011）は，宮城県松島湾内の 2 地点 で採集したサキグロタマツメタの卵塊の粒径を計測した結 果，いずれも粒径 $0.075 \sim 0.425 \mathrm{~mm}$ （原文では細砂）の割 合が高いことを報告している。本調査地においてサキグロ タマツメタの卵塊を 10 月〜 12月に確認しており（木下・ 松政未発表)，また調査範囲内で卵塊を形成途中の成貝も 発見していることから，本調査地内でサキグロタマツメタ が再生産を行っていると考えられる。したがって, サキグ ロタマツメタが Area C に多く分布する理由として, 卵塊の 形成に用いる砂の割合が調查範囲内で最も高いことが考え

Apr 2013 - Mar 2014

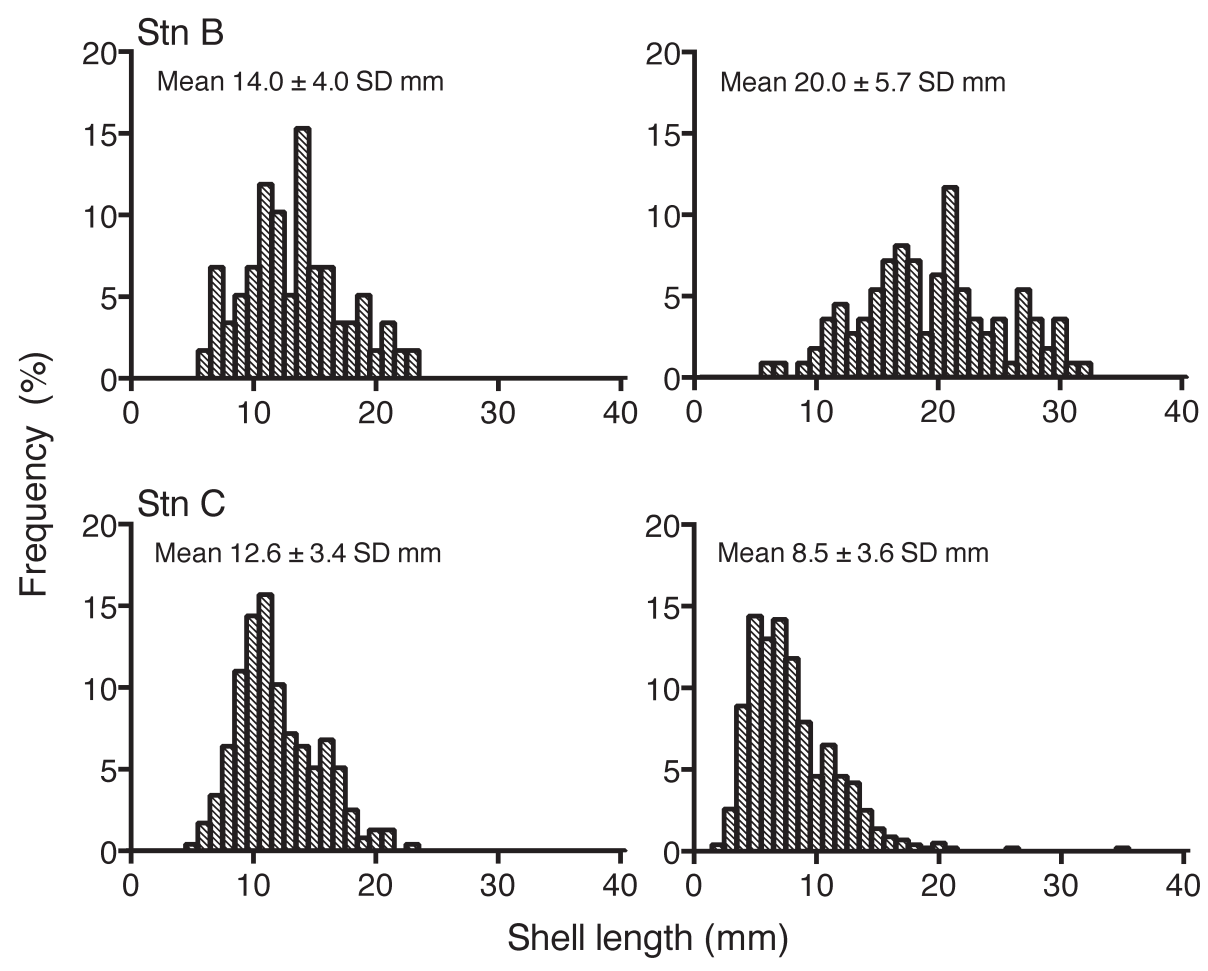

Fig. 8. Frequency distribution of drilled seashells of Ruditapes philippinarum. 
られる。今後は, 織笠川で採集された卵塊の粒度組成を調 べ, 本種の分布域の粒度組成との比較を行う必要がある.

\section{サキグロタマツメタが貝類群集に与える影響}

織笠川の河口域における貝類の優占種はアサリであっ た.サキグロタマツメタが最も多く発見された Area Cで はアサリの密度が減少し, 被食痕のある貝款が最も多く発 見された（Table 1)。これらの結果から，サキグロタマツ メタはアサリ個体群に影響を及ぼしていることが明らかに なった。一方で, Stn A ではサキグロタマツメタの捕食に よると考えられるアサリの密度の減少は認めらなかった (Fig. 6; Table 1) ことから, 織笠川の河口域のアサリはサ キグロタマツメタによる食害を受けていても，個体群は維 持されていることが示された．東北沖地震の津波被害を受 けた干潟において, 地震後にアサリの調査を行った報告に よると, 福島県松川浦のアサリの平均密度は 796 個体 $/ \mathrm{m}^{2}$ （ただし，殸長 $15 \mathrm{~mm}$ 未満の稚貝のみを対象. 密度が最も 高い地点では 2,606 個体 $/ \mathrm{m}^{2}$ )（佐藤ら 2016）, 東北沖地震 によって干潟と化した宮城県舞根湾の平均密度は 381 個体 $/ \mathrm{m}^{2}$ （千葉ら 2013）であった。織笠川のアサリの密度は, サキグロタマツメタの影響が小さい Stn A であっても，他 の被災地の干潟と比べて高いとはいえない.これが東北沖 地震からの回復過程であるためなのか, アサリの増殖を妨 げる要因があるのかは不明である。アサリの資源管理を行 なう上で，アサリの生活史や生息環境の情報が必要である （石岡ら 1999; 柿野 2002; 斉藤ら 2007）が, 本海域では知 見がない，織笠川で潮干狩りイベントを再開するために は, アサリの生態や干潟環境の調査が必要になるだろう.

捕食痕のあるアサリの貝殼の平均殼長は, 調査期間と調 查地点（Stn B，C）ごとに異なり，特に Stn Cでは2014〜 2015 年に採集された被食痕のある貝殼の平均殼長は $8.5 \mathrm{~mm}$ と小さかった（Fig. 8).これは，アサリの殼長分 布が調査地点によって異なること（Fig. 7）が反映された と考えられる. Chiba \& Sato（2012）は室内実験によって, サキグロタマツメタの捕食を受けやすいアサリの殼長は 10〜25 mmであることを示している. また本研究では, サキグロタマツメタの殼高と被食個体のアサリの殼長に相 関は認められた（Fig. 5A）が, サキグロタマツメタの壳 高と被食捕食係数の間には相関が認められず, 被食捕食係 数の平均は 0.53 であった（Fig. 5B）. 田邊（2012）は, 宮 城県のアサリ漁場 2 地点において被食痕（原文では穿孔 痕）のある貝殼を採集し, 穿孔径からサキグロタマツメタ の殼高を推定して貝殼の殼長との関係を調べ, 本種の被食 捕食係数は $0.7 \sim 0.8$ あるると報告した. 酒井・須藤 （2005）はサキグロタマツメタが自身の殼高と同サイズ〜 $10 \%$ ぼ、型の殼長のアサリを捕食することを報告した。 これらにより, 織笠川河口のサキグロタマツメタは餌に最 適なサイズのアサリよりも小型の個体を捕食していること が示唆される。サキグロタマツメタは捕食に最適なサイズ
の餌生物の密度が低下し, 代替可能な生物がいれば，捕食 対象種を変えることが知られている（Chiba \& Sato 2013; 2014).しかし本調査地では，アサリの代わりになる貝類 の密度が低いことから，サキグロタマツメタは最適な大き さよりも小型であってもアサリを捕食していると推測され た。アサリは日本の重要な水産生物であるが，アサリの国 内の漁獲量は1984 年から減少している（松川ら 2008）. このため，アサリ資源の回復に向けたさまざまな事業が実 施されている（例えば堤ら 2002; 生田ら 2009）。特にアサ リの資源の減少要因として食害による影響も大きく，食害 を防除することにより，アサリの生残に大きな効果をもた らすことが知られている（重田・薄 2012）。本研究の結果 から，礫の底質はサキグロタマツメタによるアサリの食害 を抑制することが示唆されたことから，サキグロタマツメ タの食害対策として礫の活用を検討することは有効である と考えられる.

\section{東北沖地震後の底質環境がサキグロタマツメタを含む貝類 群集に与えた影響}

東北沖地震前にサキグロタマツメタが分布していた海域 では, 地震後の 1 回の調査ではあるものの, アサリは発見 されたが, 本種と被食痕のある貝殼は確認されなかった. サキグロタマツメタは水深 $15 \mathrm{~m}$ までの浅海域に分布する ことが知られている（奥谷 2000）。したがって，東北沖地 震前の分布域で本種を確認できなかったことは，地盤沈下 にともなう地盤高の変動以外の要因であると考えられる. 本種の東北沖地震前の分布域を調査するにあたり，エクマ ンバージ採泥器（離合社製，ウェート付）を用いて堆積物 の採集を試みたが，礫が多いために採集できず，粒度組成 を調べるための試料を得ることはできなかった，東北沖地 震前にサキグロタマツメタが分布していた海域の底質は, 情報が不足しているために十分な議論を行うことは難しい ものの, 地震後に変化した可能性がある.

本研究により, 東北沖地震後の織笠川の河口域の底質は, 砂質から礫の割合が高い場所まで異質性に富んでいること が明らかになった。この底質の異質性は，サキグロタマツ メタ個体群の東北沖地震の影響からの回復に寄与したとも 言えるが，アサリなどの貝類にとっては捕食者を排除する 効果をもたらし, 地震後の個体群の回復に貢献していると 考えられる．津波などの擋乱による底生生物群集への影響 は, 擋乱直後の物理的な環境改変に対する個体群の応答が 注目される（金谷ら 2012; Seike et al. 2013; Urabe et al. 2013） が，擋乱後の長期的な回復状況は環境要因によって変化す ることが示されている（Whanpetch et al. 2010）。擋乱後の底 生生物群集の遷移過程を明らかにするためには，対象生物 と生息環境のモニタリングを併せて実施する必要がある. さらに防潮堤や水門の建設などの災害復旧事業にともない, 沿岸環境の変化が予想される。今後，織笠川の砂の割合が 増加すれば，サキグロタマツメタの分布域が拡大し貝類へ 
の捕食の影響が大きくなる可能性があることから, 東北沖 地震後の人為的な環境改変がサキグロタマツメタを含む底 生生物群集に及ぼす影響について明らかにする必要がある.

謝 辞: 本研究の調查を進めるにあたり, 調査へのご協力とご 配慮をいただいた三陸やまだ漁業協同組合, 船越湾漁業協同組 合, 山田町役場水産商工課, 株式会社山下組に御礼申し上げる. 内田明氏，萬文俊氏，佐々木浩徳氏，蛇石準哉氏には織笠川の开 キグロタマツメタに関する情報をいただいた。内野敬氏には採泥 器を作成いただき，使用方法についてご指導をいただいた，澤井 雅幸氏および岩手大学の学生諸君には野外調査の補助をいただい た。昆昌氏には船上調査の際にご協力いただいた。大越健嗣博士 にはサキグロタマツメタの調査方法に関する有益な助言と, 本論 文の校閲をいただいた。 また, 査読者 2 名には多くの有益なご指 摘をいただいた。皆様に心より御礼申し上げる。本研究は東北マ リンサイエンス拠点形成事業（海洋生態系の調査研究）および SANRIKU (三陸) 水産研究教育拠点形成事業の一環として実施 した.

\section{引用文献}

Buhle, E. R. and J. L. Ruesink 2009. Impacts of invasive oyster drills on Olympia oyster (Ostrea lurida Carpenter 1864) recovery in Willapa Bay, Washington, United States. Journal of Shellfish Research, 28: $87-96$.

Chiba, S. and S. Sato 2012. Size-selective predation and drillhole-site selectivity in Euspira fortunei (Gastropoda: Naticidae): implications for ecological and paleoecological studies. Journal of Molluscan Studies, 78: 205-212.

Chiba, S. and S. Sato 2013. Invasion of Laguncula pulchella (Gastropoda: Naticidae) and predator-prey interactions with bivalves on the Tona coast, Miyagi prefecture, northern Japan. Biol Invasions, 15: 587-598.

Chiba, S. and S. Sato 2014. Invasion of a naticid predator and associated changes in death assemblages of bivalve prey in northern Japan: implications for palaeoecological studies. Lethaia, 47:4-14.

千葉 晋・園田 武・藤浪祐一郎・浜口昌巳 2013. 舞根湾に蘇っ た干潟におけるアサリの出現と動態. 津波の海に生きる未来創 生 II 一その後の気仙沼舞根湾調査一. 海洋と生物, 35: 575-581.

原口 強 - 岩松 暉 2011. 東日本大震災津波詳細地図 上巻 青 森・岩手・宮城, 古今書院, 東京, $167 \mathrm{pp}$.

生田和正・日向野純也・桑原久実・辻本哲郎 2009. アサリと流域 圏環境一伊勢湾・三河湾での事例を中心として. 水産学シリー ズ 161 , 恒星社厚生閣, 東京, $162 \mathrm{pp}$.

石岡宏子・浜口昌巳 ・薄 浩則 - 立石 健 - 山本 翠 - 井手尾 寛・岩本哲二 1999. アサリ育成漁場の環境特性. 瀬戸内海区水 産研究所研究報告, 1: 15-37.

柿野 純 2002.アサリの生息と物理環境. 日本ベントス学会誌, 57: $158-167$.

金谷 弦・鈴木孝男 - 牧 秀明 - 中村泰男 - 宮島祐一 - 菊地永 祐 2012. 2011 年巨大津波が宮城県蒲生潟の地形, 植生および 底生動物相に及ぼした影響. 日本ベントス学会誌，67:20-32.

環境省自然環境局 2013. 平成 24 年度東北地方太平洋沿岸地域自 然環境調査等業務報告書. 環境省自然環境局生物多様性セン ター, 山梨, http://www.shiokaze.biodic.go.jp/24sokuhou_h24report. html (閲覧日 2016 年 2 月 1 日)

木下今日子 2016. リアス海岸の干潟の底生動物は震災後にどう なったのか. 日本生態学会 (編), 生態学が語る東日本大震災, 文一総合出版, 東京, pp. 89-95.

Kinoshita, K. and M. Matsumasa 2016. Effects of the Great East Japan
Earthquake on intertidal macrobenthos in Iwate Prefecture. In Ecological Impacts of Tsunamis on Coastal Ecosystems, Urabe, J. and T. Nakashizuka (eds.), Springer Japan, Tokyo, pp. 133-149.

松川康夫・張 成年・片山知史・神尾光一郎 2008. 我が国のア步 リ漁獲量激減の要因について. 日本水産学会誌, 74: 137-143.

日本ベントス学会（編）2012. 干潟の絶滅危惧動物図鑑一海岸ベン トスのレッドデータブック, 東海大学出版会, 神奈川, $285 \mathrm{pp}$.

大越健嗣 2004. 輸入アサリに混入して移入する生物一食害生物开 キグロタマツメタと非意図的移入種. 日本ベントス学会誌，59: $74-82$.

大越健嗣・大越和加（編）2011. 海のブラックバス サキグロタ マツメ夕 外来生物の生物学と水産学, 厚生社厚生閣, 東京, $244 \mathrm{pp}$.

大越健嗣 - 山内 束 2011. 成熟と産卵, 初期発生と成長, 大越健 嗣・大越和加 (編), 海のブラックバス サキグロタマッメタ 外来生物の生物学と水産学, 厚生社厚生閣, 東京, pp. 50-86.

奥谷喬司 2000. 日本近海産貝類図鑑, 東海大学出版会, 東京, $1173 \mathrm{pp}$

斉藤英俊 ・泊野洋治 - 山地幹成 - 河合幸一郎 - 今林博道 2007. 広 島県沿岸域におけるアサリの資源特性と生息環境. 水産増殖, 55: $331-345$.

酒井敬一 2000. 万石浦アサリ漁場におけるサキグロタマツメタガ イの食害について。宮城県水産研究開発センター研究報告, 16: 109-110.

酒井敬一・須藤篤史 2005 . サキグロタマツメタの初期生態につい て. 宮城県水産試験場研究報告, 5: 55-58.

酒井敬一・須藤篤史 2006 . サキグロタマツメタ防除のためのアサ リ漁場の改良. 宮城県水産試験場研究報告, 6: 83-86.

三冬社編集部 2013. 災害と防災・防犯統計データ集 東日本大震 災保存版, 三冬社, 東京, $352 \mathrm{pp}$.

佐藤正典 - 田北 徹 2000. 有明海の生物相と環境. 佐藤正典 (編), 有明海の生きものたち, 海游舎, 東京, pp. 10-35.

佐藤太津真・岩崎高資・阿部博和 2016. 松川浦におけるアサリ浮 遊幼生と稚貝の発生状況. 福島県水産試験場研究報告, 17: 8389.

Seike, K., K. Shirai, and Y. Kogure 2013. Disturbance of shallow marine soft-bottom environments and megabenthos assemblages by a huge tsunami induced by the 2011 M9.0 Tohoku-Oki earthquake. PLoS ONE, 8: e6541.

重田利拓・薄 浩則 2012. 魚類によるアサリ食害一野外標本に基 づく食害魚種リスト一。水産技術，5:1-19.

須藤篤史 2011. 食害防除・駆除対策. 大越健嗣・大越和加（編）, 海のブラックバス サキグロタマッメタ 外来生物の生物学と 水産学, 厚生社厚生閣, 東京, 135-156.

田邊 徹 2012. サキグロタマツメタの殼高とアサリを捕食時の穿 孔径との関係. 日本水産学会誌, 78: 37-42.

冨山毅・鈴木孝男 - 佐藤利幸 - 加藤 靖 - 龟岩翔太 - 杉林慶 明・大越健嗣 2011. 外来性巻貝サキグロタマツメタの松川浦に おける移入および分布. 日本水産学会誌，77: 1020-1026.

鳥越兼治・稲葉明彦 2011. 西宮市貝類館研究報告 第 7 号, 西宮 市貝類館, 兵庫, $133 \mathrm{pp}$. + 図版 $4 \mathrm{pls}$, 索引 $15 \mathrm{pp}$.

堤 裕昭・石澤紅子・冨重美穂・森山みどり・坂元香織・門谷 茂 2002. 緑川河口干潟における盛砂後のアサリ (Ruditapes philippinarum）の個体群動態. 日本ベントス学会誌，57: 177187.

Urabe, J., T. Suzuki, T. Nishita and W. Makino 2013. Immediate ecological impacts of the 2011 Tohoku earthquake tsunami on intertidal flat communities. PLoS ONE, 8: e62779.

Whanpetch, N., M. Nakaoka, H. Mukai, T.Suzuki, S. Nojima, T. Kawai and C Aryuthaka 2010. Temporal changes in benthic communities of seagrass beds impacted by a tsunami in the Andaman Sea, Thailand. Estuarine, Coastal and Shelf Science, 87: 246-252. 